\title{
A Question of Identity \\ Vocation, Professionalization, and Atla Membership
}

\author{
James Estes, Wesley Theological Seminary \\ Shaneé Yvette Murrain, University of West Georgia \\ Sandy Shapoval, Phillips Theological Seminary \\ Megan Welsh, University of Colorado Boulder
}

\begin{abstract}
Who are we as theology librarians, and what does involvement in Atla mean to us? Does serving as a theology librarian signify an exercise in religious vocation and is our association a faithbased organization with professional dimensions? Or are we librarians in a professional association concerned with content in theology and religious studies?" There are different responses to this query, and these differences can lead to tension as theology and religious studies librarians with diverse perspectives work together to build a shared future in Atla. The panelists-representing different faith traditions, institutional settings, educational and professional backgrounds, and perspectives on their work as librarians-reflect on their roles as theology and religious studies librarians with regard to three guiding prompts: (1) What is your sense of vocation and identity as a librarian? (2) How does Atla function for you, in terms of spiritual formation and/or professional development? and (3) What do you want from Atla?
\end{abstract}

\section{JAMES ESTES, WESLEY THEOLOGICAL SEMINARY}

Good afternoon, and welcome to our session on professional identity and membership in Atla. My name is James Estes, and I am the director of the library at Wesley Theological Seminary, where I also teach church history and medieval studies. While mine is the least important voice you're going to hear this afternoon, I have the pleasure and the privilege of introducing our topic and our panelists. Let's start with the people you're here to hear: joining us today are Shaneé Yvette Murrain, University Archivist and Assistant Profes- 
sor at the University of West Georgia; Sandy Shapoval, Dean of the Library and Research Services at Phillips Theological Seminary; and Megan Welsh, Assistant Professor and Interdisciplinary Arts and Humanities Librarian at the University of Colorado Boulder. I'm happy and honored that they are joining us to reflect on their work as library professionals and members of Atla. Before we turn to our discussion, however, my colleagues and I would like to respectfully acknowledge that we are gathered today on the traditional territory of the Musqueam, Squamish and Tsleil-Waututh peoples.

Let's start with the big picture: Who, or what is Atla? ATLA-as the American Theological Library Association-was authorized in 1946 by the American Association of Theological Schools (now the Association of Theological Schools in the United States and Canada) to "study the distinctive problems of theological seminary libraries," in part to address the issue of accreditation. ${ }^{1}$ As a product of largely mainline Protestant theological education, the theological and formational dimensions of theology librarianship were never far from the surface. Raymond Morris asserted in his 1953 ATLA address that "theological librarianship is at its best a ministry"-an address which Carisse Berryhill calls the "touchstone articulation" of the vocation of theology librarianship for many theology librarians. $^{2}$

Things have changed considerably. The organization that was created by the ATS to address the problem of Protestant theological school libraries now has an expanded, comprehensive vision for librarianship and scholarly communications in theology and religious studies. As Atla itself offers,

Atla is a membership association of librarians and information professionals, and a producer of research tools, committed to advancing the study of religion and theology. Our membership includes more than 800 individuals and libraries at academic institutions from diverse religious traditions and backgrounds. As a community of collectors and connectors, Atla works to promote worldwide scholarly communication in religion and theology by advancing the work of libraries and related information providers. ${ }^{3}$ 
We have, then, the historic ATLA and the present Atla, and I believe it's safe to say that the latter is historically linked but no longer existentially bound to the tradition of Protestant Christian theological education. I would suggest that this has caused some tension within the association as some members of Atla may hold divergent, even dissonant visions of our work together. Thus, the reason for us coming together today. If we are no longer solely an association of librarians whose focus is theological education, then who are we and how do we envision our work together? While this question cannot be answered neatly in a single conversation, it's a dialogue worthy of attention.

Before I turn to our colleagues, I want to highlight the three important questions that emerged as we collaborated on this panel: (1) What is your sense of vocation and identity as a librarian? (2) How does Atla function for you? (Is it for spiritual formation, professional development, or both?) and (3) What do you want from Atla? Let's keep these questions in mind as kind of a roadmap for our conversation this afternoon, and now-let's begin.

\section{SHANEÉ YVETTE MURRAIN, UNIVERSITY OF WEST GEORGIA}

\section{What is your sense of vocation and identity as a librarian?}

I can point to a childhood experience involving faith, community, and representation for how and why I came to do the work which makes my life sweet. One evening during the summer I turned six years old, my aunt Denise and I took a walk around the Spanish Harlem neighborhood my family has called home for three generations. Both my maternal and paternal branches staked claim to a side of 3rd Avenue after departing the American South, Puerto Rico, and St. Thomas for better opportunities. The details about our purpose or intended destination escape me, but what is seared in my memory is how formative that walk has become to my entire life and vocation. Our trek led us past my favorite mural, Hank Prussing and Manuel Vega's iconic “The Spirit of East Harlem," immortalizing fifty-three residents of the largely Puerto Rican community. With fondness of that familiar image in mind, we approached a gruesome mural depicting the crucified Christ. It stopped me dead in my tracks. I looked to Titi Denise for counsel. She raptly uncovered a cross from her neck to underscore, "This is Christ who died for 
you!" Needless to say, I was absolutely traumatized and spent years attending different religious services trying to understand why people built their lives and best efforts around this particular story. I became further transfixed with church culture while pursuing my BA in Religion and Philosophy.

The year 2008 found me in seminary, continuing this interest in African American church history. In the final year of the MDiv program, I was introduced to librarianship by Dr. Ernest Rubenstein, Theological Librarian at Drew University. My primary objective for considering the field was to create an open-access database for scholars and laypeople to study Black church history. Shortly after enrollment in the MLS program at North Carolina Central University, I scheduled a meeting with the University Archivist to learn about Special Collections. I was told about the digitization of Durham's White Rock Baptist Church papers and was offered a grant-funded position working on the larger CCC project. A few years into working with religious materials at Duke, a post for an archivist to coordinate a digitization project at a historic Black seminary caught my eye. Once my work on that project was complete, a colleague encouraged me to apply to the University Archivist position at the University of West Georgia where there was an opportunity for me to create and lead a church-based community archives initiative.

\section{How does Atla function for you? Is it for spiritual formation, profes- sional development, or both?}

Becoming involved in Atla has been crucial for my professional development. Shortly after joining the organization in 2012, I was appointed to the Diversity Committee (2014-2016). This appointment gave me the unique opportunity to use committee work as leverage for enacting real organizational change.

During our Fall planning meeting, I proposed we design a preconference workshop to identify the benefits of inclusiveness in ATLA and ways to increase racial equity in theological librarianship, including training in the awareness of the impact of racism on institutions and the steps necessary for interrupting racist structures. The conversations resulting from the workshop led to a committee name change and updated charge to reflect ATLA's revised core values. 
On June 17, 2015, I was moderating a panel discussion and preconference workshop on Racial Equity in Theological Librarianship at the ATLA annual meeting in Denver, Colorado, with other members of the Diversity Committee. There was rich, honest, vulnerable dialogue and a resolve among the small number of attendees to continue the conversation within the larger professional association and back home in our practices at home libraries. I checked my phone the evening of June 17th after a full day of diversity training to find Tumblr, flooded with stories about the Mother Emanuel shooting. The story was a bit slow to hit national news; social media is more and more showing itself to be the better tool for "breaking news."

The President of ATLA announced at the plenary session the next morning that nine Bible Study attendees had been murdered at Mother Emanuel AME Church in Charleston, South Carolina. The crowd of librarians, many holding tablets and smart devices gasped. Loudly. I was surprised that so many hadn't heard. I understood we were a bit isolated by travel and attending the conference, but these were librarians, who I believed were pretty good about being aware of what's going on in the world.

After the session, I ran into Methodist librarian Chris Anderson and fellow millennial and AME Zion librarian Jess Bellemer in the vendor hall. I knew we couldn't be the only ones talking about this hate crime and connecting it to the pre-conference workshop on diversity and inclusion. Jess and I came up with a plan of action. We organized a lunchtime chat at the hotel restaurant with the ATLA President and Director of Member Programs for those who wanted to talk about the tragedy. ATLA staff graciously agreed to cover the meals of all attendees.

Quite a few members of the Board of Directors attended and were extremely active in the conversation. Jess and I worked throughout the afternoon to petition the Board to formulate an official response to the act of terrorism, which I read aloud at the end of the Business Meeting. The Board convened a special meeting to which Jess and I were invited as special guests, though Jess did not attend. There were concerns raised from other members about where ATLA stood as far as politics, activism, and diversity. We drafted a proclamation that was read at the closing plenary on the basis that ATLA contrib- 
utes to the formation of religious leaders and librarians.

The conversation continued post-conference on our online listserv. I shared the quickly developing Twitter crowd-sourced \#CharlestonSyllabus I'd discovered on the plane ride home from the conference. Some of the conversations concerning the right to bear arms and fly the Confederate Flag were hard to read, other messages (many sent to me off the list) made me proud and optimistic about my membership in the organization and my role in bringing awareness to the tragedy.

\section{What do you want from Atla?}

Now as a board member, I've been witness and participant in the rebranding of Atla and conversations around increasing diversity in the association. I want from Atla something I want from all the groups of people I interact with professionally: respect, and if at all possible, the radical expression of hospitality that is being left to be. I'll be completely transparent here and say that while I find great value in attending annual meeting, each year I am left completely drained by the experience. I am repeatedly microaggressed by members who are startled, uncomfortable or seemingly unfamiliar with me (though we've met countless times and my face is now the introductory image on the website). As a result, Atla is not a body that contributes to my spiritual formation, but it does strengthen my vocational resolve to remain present, actively engaged and vocal. I appreciate those with whom I've built genuine relationships over the years and want to recognize the Special Collections and Archives Interest Group, who are some of the best Special Collections Librarians I've ever met, and I remain hopeful that Atla will be a place where all the folks who feel underrepresented or have experienced harm find what they need and expect the association and our membership to provide.

\section{SANDY SHAPOVAL, PHILLIPS THEOLOGICAL SEMINARY}

What is your sense of vocation and identity as a librarian?

My librarianship extends from a sacred sense of service: being an agent in sharing the recorded conversations of humanity that lead to furthering wisdom in this life. I marvel that I am in a position to 
fulfill this sense of being; the word “gratitude” doesn't even cut itit's an amazement.

I love my work at Phillips Theological Seminary where I serve as Dean of the Library and Research Services. The ensemble and interconnected approach that feels most natural to my work identity is nurtured by the integration of our librarianship into the structure of Phillips. The library is both a pedagogical and a technological partner of the seminary. My management style is collaborative, and I try to reflect the integrated nature of the seminary's work throughout my relationships with the other librarians.

I belong to the Unitarian Universalist tradition, a non-creedal, covenantal, congregational, and progressive denomination historically seated within the Judeo-Christian tradition. Phillips is historically Christian Church (Disciples of Christ), and has become explicitly progressive in recent years, a natural outgrowth of the Disciples' ecumenical tradition. We currently serve students from nineteen denominations. As an institution we are an important part of the interfaith and social justice fabric of the Tulsa, Oklahoma, area and larger region. This orientation is framed by our identity phrase which emphasizes our theological interpretation of the Gospels: "We are dedicated to learning the way of Jesus [emphasis added] in order to cultivate vital congregations, communities, conversations and the public good." 4

This institutional orientation facilitates a mechanism whereby I am able to exercise my ethical core: the dissemination of information to our community for the purpose and hope of enabling their attainment of the wisdom necessary to navigate our very choppy societal waters. Our faculty, students, and alums are frequently called upon to publicly address challenges to the Judeo-Christian theological foundation that we are all made in the image of God. It is the work of our library to make sure the community has access to the record of conversation partners that inspire creative responses in difficult times. In other words, I see the right to transmission of knowledge as divine.

My vocational identity is missional in this sense. My larger hope lies in bringing people into conversations that support change which nurtures the respect inherent in the Imago Dei. 


\section{How does Atla function for you? Is it for spiritual formation, profes- sional development, or both?}

As much as my place of work functions as a frame for spiritual formation for me, Atla functions chiefly as a professional skills-development apparatus for my trajectory. It supports the technical expertise-honing I need in order to better exercise the aims of my professional identity and goals. This professional support framework is very important to me; there is no other organization that fulfills this piece. Each year I look forward to the Atla conference as an energizing opportunity to continue learning, renewing, and refining ideas.

I do occasionally find my "spiritual" aspect is engaged when conversations with other members touch on such topics as the philosophical aspects of learning and reading processing, a tad of the epistemological. I find these conversations deeply fulfilling, and they provide a sense of at-home-ness for me in knowing I am with others like me. But generally, I am feasting on ideas that move my craft forward among colleagues who challenge and teach me. Atla offers a space and opportunity for me to push my technical edge with others who possess an intensity of purpose that can equal that which they bring to the exercise of their religious faith: worshipful and seeking. I feel we all share this double-mapping, or spiritual overlay, with our work.

I am still chewing on my only real disappointment with Atla. During 2012, the year the annual conference was held in Scottsdale, the Arizona politicians of the day had passed laws censoring textbooks, attempting even at the university level to remove the narrative of non-European struggle and achievement from their educational system. I watched these events unfold across our national networks, and I viewed these acts as demonic-they transgressed my sense of the divine that manifests as the right to transmission of knowledge, and they transgressed the right of marginalized cultures to exist even in concept, an attempted x-ing out of the Imago Dei. As such I thought it a natural extension of ATLA-librarianship in conjunction with the Judeo-Christian tradition of access to The Book-to participate in the anti-censorship protests building in the Phoenix area. The American Library Association was forthcoming with its position, passing a resolution in January of 2012 condemning the actions of the Arizona government. ${ }^{5}$ I received communication from ATLA's leader- 
ship, however, that I could not use ATLA's communication structure (ATLANTIS) for discussion on the matter, but I was free to speak in non-ATLA modes:

ATLA is not a political advocacy organization, and advocacy related to this issue does not further the mission or organizational ends. Our membership is diverse and represents a wide range of viewpoints, and our neutral stance on political issues of all kinds reflects our respect for individual members' right to their own personal viewpoints. ${ }^{6}$

Clearly there were members of the association who held the policies of cultural information suppression as just and necessary, and ATLA would not offend these colleagues. ATLA would be an organization for the craft of librarianship, despite the fact that censorship is an existential threat to its being, and has no social justice component, even in the face of censorship.

This disappointment is heavy still, and I will talk more about this in the next question.

\section{What do you want from Atla?}

My hope is that as Atla's sphere expands into a globalized and religious studies-supporting organization it will feel more authorized to act on the existential threat of knowledge suppression. I hope that the respect and welcoming of broader ways of religious being in the world will accompany a more courageous stance in confronting difficult conversations about allowing censorship that demeans, and attempts to further shame, competing religious ideas.

There seems to me to be a place for faith activity beyond traditional worship settings that we see at Atla, activities that would not shy away from asking what it means to be attentive to God, or the Ultimate, if you will. And so, I wonder: Is anti-censorship activism, especially that which relates to the preservation of non-dominant historical traditions-which are inevitably part of the competition of religious ideasours to engage in at Atla?

Language from Atla's core values includes "widest possible access to relevant information and ideas," and "hospitality, inclusion, and diversity." 
The first item under the "Atla exists so that" enumeration states:

Professionals engaged in librarianship and scholarly communication are advocating and collaborating in order to advance scholarship in theological and religious disciplines.

a. Librarians and scholarly communication professionals are developing and strengthening connections that lead to innovative solutions for shared challenges.

b. Librarians and scholarly communication professionals are developing increased capacities to work in diverse and changing environments [emphases added]. ${ }^{8}$

I hope that these aspirations are not meant only to focus on the economic challenges of obtaining our resources and technological means to serve-which are deep and are many. If we do not have a strategy to challenge threats to the principles underlying the very need for these technologies and financial resources, then, as I see it, we are in peril. A cursory look at current politics with the dismantling of scientific information for the furthering of certain faith beliefs over others in the United States should indicate that the specter of broader silencing of religious ideas is not necessarily far-fetched.

The Atla website says, "We are curators, disseminators, and aggregators." ${ }^{\prime}$ But should we not also be defenders? If a value of anticensorship is included in Atla's core list we would have a mechanism to address threats to the legality of the existence of our religious content.

\section{MEGAN WELSH, UNIVERSITY OF COLORADO BOULDER} What is your sense of vocation and identity as a librarian?

I'm going to flip this first question slightly and answer the "identity" piece first. I don't think I can talk about my sense of vocation without first talking about my sense of identity.

\section{Identity}

That said, I'm approaching sharing my identity with a sense of nervousness and this comes from the fact I have rarely talked about 
my own personal religious affiliation in professional settings and especially not in this one. I wonder if in sharing this aspect of myself, some will consider me a fraud within an organization which broadly seems to celebrate the intersection of personally held religious beliefs and professional practice.

Spoiler alert: I am not someone who nurtures this intersection of religious belief in my librarianship.

My relationship with God is a personal one that goes beyond doctrine and transcends the religious tradition I was born into. Although this is a personal relationship, I feel, as an Atla member attending this conference, I have to and, indeed, today, am choosing to make it a public phenomenon.

I consider myself a Cultural Catholic, someone who was raised in the Roman Catholic Church, but who does not go to Church regularly and whose relationship with the divine is not confined to religious doctrine.

This background and how I currently define myself lends to a sense of imposter syndrome, another aspect of my identity which presents itself in my librarianship. I'm so impressed by all of you who are ordained. I'm so impressed by your many degrees in all aspects of religion, higher education, and librarianship. I'm impressed by the faith some of you maintain that fosters connection with your students. My curiosity functions in a similar way, allowing me to connect with my patrons who are actively pursuing their inquiry into religion, but ultimately, I don't have that faith that I bring to my librarianship.

It can be very intimidating being in a room with all of you welleducated, grounded colleagues and I realize that, by presenting some of the reasons why I feel intimidated, I'm also making assumptions about who all of you are out there and I encourage you to push back and challenge these assumptions and share what drives your professional identity.

I have felt this imposter syndrome rear its ugly head while being invited to pray at this conference and while being asked what denomination I am; while hearing some fellow Atla members grumble about the session on inclusivity sponsored by DEI that we had in Long Beach, while hearing my colleagues' express that their lived experiences were minimized, sometimes through microaggres- 
sions and other times more explicitly. It has taken me a little while to realize that, beyond this sense of imposter syndrome, what I was also feeling was the potential for exclusion, either for myself or for colleagues who I've come to see as friends.

One of the times that I have felt a disconnect from my colleagues was when I was invited to present at the Philosophical, Religious, and Theological Studies Discussion Group meeting at ALA Midwinter in 2018. My presentation, subtitled "Ideas of the Holy," discussed interfaith work and how the academic library can be a center for such work, facilitating inclusion of patrons from all faiths. Reactions to the presentation were either really positive or really negative. Here I thought I was being clever re-envisioning Otto's title, but some people actually expected a more theological, Christian-focused presentation. I left that presentation surprised and thinking, "Why did people expect such a different presentation than what I delivered? This isn't a presentation in front of Atla colleagues!” I double checked to make sure I didn't misread the title of the group, that it actually included "philosophical" and "religious" in the name of the group and not just "theological." My gut reaction indicates a sort of complacency that such a presentation might garner "controversy" or a negative reaction if I had given it at Atla.

\section{Vocation}

So, while I do not feel a sense of vocation in a religious sense, while I do not feel called to this role as a Religious Studies Subject Specialist, I do feel called to be and do the best that I can in this role. That is my vocation.

So if I think of elements of vocation as what am I inspired and compelled to do, I come up with three areas of focus in my professional practice that I'd like to share (y'all are catching me at a great time - I have to submit my tenure documentation at the end of this month so I've been thinking a lot about what I've been doing and how I am doing that job excellently over the past six years):

1. Mentor. I feel strongly that it's important to train the next generation of emerging library professionals. I've been lucky to mentor a graduate student from the Religious Studies Department and MLIS students at the Reference Desk. 
2. Innovate. Generate and act on ideas, especially to build community and relationships; especially to engage our most underserved populations and those who feel least comfortable in the libraries. Need to acknowledge that the academic library is, in and of itself, regardless of religious affiliation, a barrier to the access it tries to provide at times. And I really want to emphasize that this is regardless of religious affiliation.

After sharing about conducting outreach that proactively sought to be inclusive of our marginalized populations at $\mathrm{CU}$ Boulder, I received comments from folks on ATLANTIS saying that my situation is different because I'm at a public university and students do not have a strong sense of right and wrong because they lack religion as a moral foundation for their academic experience.

3. Provide excellent customer service. I prioritize bringing my genuine self to my interactions with patrons, especially students in research consultations and at the reference desk; engage, with empathy and seeking to listen and understand, to facilitate a constructive learning experience.

\section{How does Atla function for you? Is it for spiritual formation, profes- sional development, or both?}

My first ATLA conference was in New Orleans and I remember awkwardly doing the newcomer's BINGO at the welcoming reception. (How many of you remember doing that?) Although I hate icebreakers like that, I've returned to be a Welcomer every single year because I love the camaraderie I have felt among colleagues in Atla and I want newbies to feel welcome as well. That is how Atla functions for me.

I will say that, although I felt welcomed at the Welcome reception at my first ATLA, I was surprised when I walked into the opening reception to see mainly older white men. I didn't realize how many men were active in theological librarianship and I questioned if I belonged there. Where were all the women? Where are the female library directors or leaders in their libraries?

Atla functions as a hub for connecting me to colleagues and as a mechanism for professional development. As I have gotten to know 
more and more Atla members, Atla has evolved to be even more a place of friendship and camaraderie.

I do hope to see Atla and all of us grow and think critically, just as we ask our students to do, about who we are as librarians, especially in a predominantly White and Christian profession and organization. I hope we can answer questions about the ways we need to evolve to better serve our patrons and how we can think more critically of our positions of authority, with whatever privilege our personal identities bring to the table.

\section{What do you want from Atla?}

In general, I am looking for support in my professional growth. This takes the form of trainings, workshops, conferences, and other forms of professional development, but it also takes the form of a robust network of colleagues who I can turn to in order to brainstorm, generate new ideas, and grow with. This ask of all of you as colleagues is much more nebulous and undefined than my asks of Atla as an organization, so I'll focus on the latter:

My asks can be summed up by saying that I'm not sure what my future holds and I don't know if I want to be a director, but I am looking for support for future growth, especially in developing leadership skills.

In order to receive this support from Atla, I would love to see the resurrection of the Wabash Colloquy. I know Atla is working on this, but regardless of when it happens, I would like to see the development of meaningful immersive, community-building training experiences around four topics:

1. Leadership, supervisory, \& managerial training. What are the skills that transcend library types (e.g., seminary versus public university); what can help someone be a leader in their libraries, whether or not they want to be a director or a supervisor?

2. Research support training, both faculty librarians and those pushing the needle to make research in the profession more rigorous and exploring how to inquire in new ways, especially by integrating technology into their research process or product. Let's be leaders in digital humanities, engaging in our own projects and also partnering with faculty as they engage in digi- 
tal humanities. I would love to see a program like the immersive, week-long experience Institute for Research Design in Librarianship (IRDL) to support rigorous research design and learning research methodologies in theological and religious studies librarianship.

3. Tech skills and library trends. Atla has worked towards this with some webinars sponsored by the Professional Development Committee and also by hosting the ACRL Scholarly Communication Roadshow in Chicago. I would love to see more learning opportunities like this where we can connect with one another in person outside of the annual conference.

4. Support for the creation of regional groups. Maybe this would help fill that need for in-person connection over learning opportunities. I'm currently not a member of one, but Stephen Sweeney and I are investigating this for the Rocky Mountain region and we already have received great support from Atla to work on this.

That's all for me. Thanks, all, for listening!

\section{CONCLUDING DISCUSSION}

The panel concluded with a dialogue with the audience. The question for the audience that shaped this conversation was, "How would you like to shape your participation in the Atla community going forward? What support systems and resources would foster your sense of identity as a theology and religious studies librarian?” The presenters asked that the audience keep in mind the final three of Atla's core values: "Hospitality, inclusion, and diversity," "Collegiality and collaboration," and "Creativity, innovation, and transformation.” ${ }^{10}$ 


\section{ENDNOTES}

1 Elmer J. and Betty O’Brien, “From Volunteerism to Corporate Professionalism: A Historical Sketch of the American Theological Library Association," in The American Theological Library Association: Essays in Celebration of the First Fifty Years, ed. M. Patrick Graham, Valerie Hotchkiss, and Kenneth E. Rowe (Evanston, IL: American Theological Library Association, 1996), 5.

2 Raymond P. Morris, "Theological Librarianship as a Ministry," in A Broadening Conversation: Classic Readings in Theological Librarianship, ed. Melody Layton McMahon and David R. Stewart (Lanham, MD: Scarecrow Press, 2006), 8; Carisse Mickey Berryhill, review of $A$ Broadening Conversation: Classic Readings in Theological Librarianship, by Melody McMahon and David Stewart, The Library Quarterly: Information, Community, Policy 77, no. 2 (April 2007): 250, https://doi.org/10.1086/517851

3 "About Atla: Collectors \& Connectors in Religion \& Theology," Atla, https://www.atla.com/about/.

4 “About Phillips," Phillips Theological Seminary, https://www. ptstulsa.edu/about-us/.

5 "Resolution Opposing Restriction of Access to Materials and Open Inquiry in Ethnic and Cultural Studies Programs in Arizona," Intellectual Freedom Blog: The Office for Intellectual Freedom of the American Library Association, https://www.oif. ala.org/oif/?p=3157.

6 Email message to author, March 26, 2012.

7 “Vision, Purpose, \& Values," Atla, https://www.atla.com/visionpurpose-values/.

8 “Mission \& Organizational Ends," Atla, https://www.atla.com/ about/mission/.

9 “Explore Our Religion \& Theology Collections," Atla, https:// dl.atla.com/.

10 Atla, "Vision, Purpose, \& Values.” 